\title{
POLIGAMI DALAM PANDANGAN POSITIVISME
}

\author{
Iri Hamzah \\ Institut Agama Islam Yasni Bungo \\ Email: erihamzah80@gmail.com
}

\begin{abstract}
Positivism is a philosophical school that states natural science as the only true source of knowledge and rejects metaphysical activities. Positivism knows no speculation, all based on empirical data, all results are based on real facts and the results have benefits and goals. poligami when viewed from positivism is highly irrelevant in the current context, this is as stated by Muhammad Abduh, According to Abduh polygamy which aims to find pleasure then it is prohibited. If the reason is intended only to meet biological needs it is not allowed, but if the reason is due to an emergency then it may be allowed to do. In this discussion positivism is more inclined to forbid polygamy than allow, this relates to the results obtained from the epistemology. that all sources of knowledge are based only on ratios and empirical facts that are real and useful. When related to the current context, polygamy by many men is more detrimental to women and brings benefits to men. then polygamy is forbidden because it is more detrimental to many parties than to favor one party.
\end{abstract}

Keywords: Polygamy, Positivisme, Islamic Legal Philosophy

\begin{abstract}
Abstrak
Positivisme adalah suatu aliran filsafat yang menyatakan ilmu alam sebagai satusatunya sumber pengetahuan yang benar dan menolak aktifitas yang berkenaan dengan metafisik. Tidak mengenal adanya spekulasi, semua didasarkan pada data empiris, di mana semua data-data tersebut berdasarkan fakta-fakta yang nyata dan hasilnyapun memiliki kegunaan dan kemanfaatan yang pasti. Permasalahan poligami apabila ditinjau dari positivisme sangat tidak relevan pada konteks saat ini, hal ini sesuai yang dikemukakan muhammad abduh, Menurut Abduh poligami yang di lakukan dengan tujuan hanya untuk kesenangan hukumnya haram. Apabila alasannya di maksudkan hanya untuk memenuhi kebutuhan biologis semata menjadi tidak boleh, tetapi jika alasannya karena darurat maka kemungkinan dibolehkannya untuk melakukan tetap ada. Dalam pembahasan ini positivisme lebih condong kepada mengharamkan poligami dari pada membolehkan, hal ini berkaitan dengan hasil yang didapat dari epistemologi tersebut, bahwa semua sumber ilmu pengetahuan hanya berdasarkan rasio dan fakta-fakta empiris yang nyata dan memiliki kegunaan yang pasti. Apabila dikaitkan pada konteks saat ini poligami yang dilakukan banyak pria lebih merugikan wanita dari pada membawa keuntungan dan kemanfaatan bagi pria, maka poligamipun diharamkan karena lebih banyak merugikan banyak pihak dari pada menguntungkan satu pihak.
\end{abstract}

Nur El-Islam, Volume 7, Nomor 2, Oktober 2020 
Kata Kunci: Poligami, Positivisme, Filsafat Hukum Islam

\section{A. Pendahuluan}

Poligami berasal dari bahasa yunani dan merupakan penggalan dari kata poliu atau polus yang berarti banyak dan gamen yang berarti perkawinan. Dengan demikian poligami dapat dikatakan perkawinan banyak dan bisa jadi dalam jumlah tidak terbatas. Atau dengan kata lain memiliki dua orang atau lebih suami atau istri pada saat yang bersamaan. Pada perkembangannya istilah ini mengalami penyempitan makna menjadi suami yang memiliki istri dua atau lebih pada waktu yang bersamaan.sedangkan istri yang memiliki dua suami atau lebih secara bersamaan disebut dengan istilah poliandri. ${ }^{1}$

Kata Positivime merupakan turunan dari kata positive John M. Echols mengartikan positive dengan beberapa kata yaitu positif (lawan dari negative) tegas, pasti, meyankinkan. Dalam filsafat, positivisme berarti suatu aliran filsafat yang berpangkal pada sesuatu yang pasti, faktual, nyata, dari apa yang diketahui dan berdasarkan data empiris Menurut Kamus Besar Bahasa Indonesia, positivisme berarti aliran filsafat yang beranggapan bahwa pengetahuan itu semata-mata berdasarkan pengalaman dan ilmu yang pasti. Sesuatu yang maya dan tidak jelas dikesampingkan, sehingga aliran ini menolak sesuatu seperti metafisik dan ilmu gaib dan tidak mengenal adanya spekulasi. ${ }^{2}$

Al- Jashash melihat status hukum poligami hanya sebatas boleh (mubah). Kebolehan yang disertai dengan syarat-syarat yang ketat. Bahkan al-maraghi menggaris bawahi syarat-syarat yang diperketat tersebut dalam keadaan yang darurat, misalnya istri mandul, suami memiliki kemampuan seks tinggi, kaya raya dan jumlah perempuan lebih banyak dari pada laki-laki. Sedangkan pengaturan dengan empat istri ini merupakan pembatasan bukan lisensi sebuah operasi baru. Dengan demikian hukum poligami pada dasarnya mubah, namun bagaimanakah sikap dan pandangan Positivesme terhadap poligami

${ }^{1}$ Sri Mulyati. (ed). Relasi Suami Istri dalam Islam (Jakarta: PSW UIN Syarif Hidayatullah, 2004), h. 81.

${ }^{2}$ M. Baqir Ash-Shadr, Falsafatuna, (Bandung, Penerbit Mizan,1995), h. 56. 
sebuah aliran filsafat yang hanya berdasarkan empiris dan data-data yang factual yang berimplikasi pada tujuan dan manfaat sesuatu, mungkinkah poligami pada konteks saat ini memiliki kontribusi nyata atau hanya sekedar pelampiasan nafsu para kaum lelaki, disini penulis akan menjelaskan dan melihat sejauh mana pandangan positivisme terhadap poligami, apakah poligami masih sangat relevan dengan konteks zaman sekarang. ${ }^{3}$

\section{B. Pengertian Poligami}

Dalam antropologi sosial, poligami merupakan praktik pernikahan kepada lebih dari satu suami atau istri (sesuai dengan jenis kelamin orang bersangkutan) sekaligus pada suatu saat (berlawanan dengan monogami, di mana seseorang memiliki hanya satu suami atau istri pada suatu saat.

Terdapat tiga bentuk poligami, yaitu poligami (seorang pria memiliki beberapa istri sekaligus), poliandri (seorang wanita memiliki beberapa suami sekaligus), dan pernikahan kelompok (bahasa Inggris: group marriage, yaitu kombinasi poligami dan poliandri). Ketiga bentuk poligami tersebut ditemukan dalam sejarah, namum poligami merupakan bentuk yang paling umum terjadi..

Walaupun diperbolehkan dalam beberapa kebudayaan, poligami ditentang oleh sebagian kalangan. Terutama kaum feminis menentang poligami, karena mereka menganggap poligami sebagai bentuk penindasan kepada kaum wanita. Islam pada dasarnya memperbolehkan seorang pria beristri lebih dari satu (poligami), Islam memperbolehkan seorang pria beristri hingga empat orang istri dengan syarat sang suami harus dapat berbuat adil terhadap seluruh istrinya (Surat an-Nisa ayat:3).

Poligami dalam Islam baik dalam hukum maupun praktiknya, diterapkan secara bervariasi di tiap-tiap negara dengan mayoritas penduduk beragama Islam. Di Indonesia sendiri terdapat hukum yang

${ }^{3}$ Mufidah, (Isu -Isu Gender kontemporer (Dalam Hukum Keluarga), (Malang, UINMaliki Press, 2010), h. 163. 
memperketat aturan poligini untuk pegawai negeri, dan sedang dalam wacana untuk diberlakukan kepada publik secara umum, Tunisia adalah contoh negara arab dimana poligami tidak diperbolehkan. Menurut Gustave Le Bon, di Eropa tidak ada praktik atau tradisi timur yang dikritik dengan begitu sengitnya selain poligami. ${ }^{4}$

\section{Poligami Menurut Pandangan Islam}

Poligami merupakan salah satu isu yang disorot tajam kalangan feminis, tak terkecuali feminis islam. Poligami adalah isyarat islam yang merupakan sunah Rasulullah SAW tentunya dengan syarat sang suami memiliki kemampuan untuk adil diantara para isteri. Sebagai mana Allah berfirman di dalam Al-Quran:

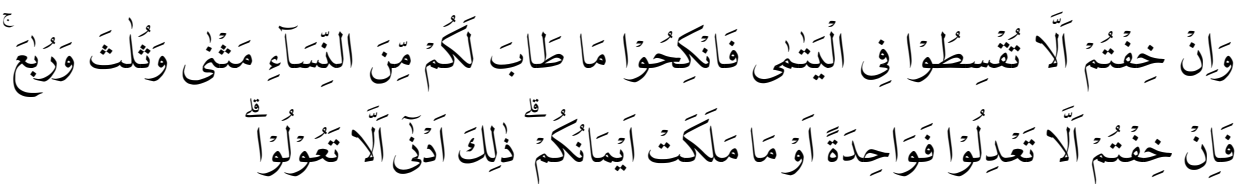

“Dan jika kamu khawatir tidak akan mampu berlaku adil terhadap (hak-hak) perempuan yatim (bilamana kamu menikahinya), maka nikahilah perempuan (lain) yang kamu senangi: dua, tiga atau empat. Tetapi jika kamu khawatir tidak akan mampu berlaku adil, maka (nikahilah) seorang saja, atau hamba sahaya perempuan yang kamu miliki. Yang demikian itu lebih dekat agar kamu tidak berbuat zalim. (Q.S. An-Nisa/ 3)

Sedangkan di ayat lain Allah berfirman

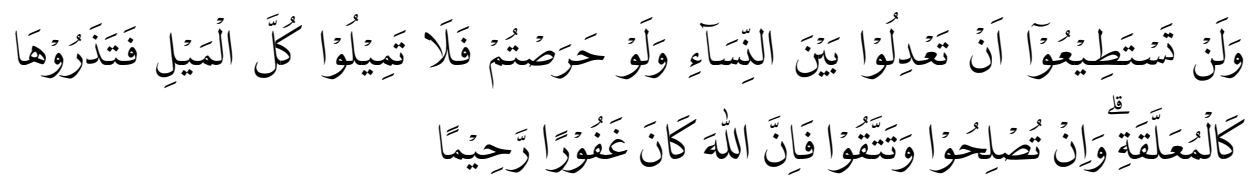

"Dan kamu tidak akan dapat berlaku adil di antara istri-istri(mu), walaupun kamu sangat ingin berbuat demikian, karena itu janganlah kamu terlalu cenderung (kepada yang kamu cintai), sehingga kamu biarkan yang lain terkatung-katung. Dan jika kamu mengadakan

\footnotetext{
${ }^{4}$ Ibid, h. 159-173.
} 
perbaikan dan memelihara diri (dari kecurangan), maka sungguh, Allah Maha Pengampun, Maha Penyayang. (Q.S. An-Nisa/129)

Pada ayat ini dijelaskan bahwa umat manusia (kaum lelaki) sesekali tidak akan mampu berlaku adil walaupun ia telah berusaha, disini tampak bahwa sejatinya Allahpun tidak mengizinkan poligami pada umat manusia kecuali hanya pada kondisi-kondisi tertentu, Selain itu, tidak adanya ayat Al-Quran dan sunah Rasulullah yang menggambarkan diperbolehkan atau dilarangnya poligami. Sesungguhnya poligami yang diatur dalam islam tidak memperbolehkan bagi laki-laki untuk berhubungan dengan wanita yang ia sukai diluar pernikahan, Poligami merupakan sistem yang manusiawi, karena dapat meringankan beban masyarakat yaitu dengan melindungi wanita yang tidak bersuami dan menempatkannya ke shaf para isteri yang terpelihara dan terjaga. ${ }^{5}$

Dalam ayat-ayat diatas penulis dapat mengetahui bahwa islam mengajarkan kita tentang bagaimana syarat-syarat bagi siapa yang hendak melakukah poligami diantaranya adalah:

1. Hukum poligami pada ayat poligami adalah hukumnya mubah, karena lafadzh fankihu walaupun berupa amr (perintah) tapi ia mengandung makna mubah bukan wajib, sebagaimana hal itu menjadi pendapat jumhur mujtahidin dalam setiap masa. Oleh karena itu pendapat yang mengatakan bolehnya berpoligami lebih dari empat, hal ini adalah pendapat yang tidak mendasar.

2. Mubahnya hukum poligami harus menjalankan syarat-syarat adil terhadap istri-istrinya. Keadilan disini bukan dalam bentuk cinta yang mustahil dibagi rata, tetapi adil disini adalah adil dalam memberikan minuman, makanan, tempat tinggal, pakaian, nafkah lahir dan batin serta membagi giliran (bermalam). Jika ia takut tidak mampu berlaku adil pada wanita yatim yang di dalam pemeliharaannya atau terlalu cinta kepada salah satu istri saja,

${ }^{5}$ Faqih, Khoyin Abu..Poligami Solusi atau Masalah. (Jakarta: Al-I’tishom Cahaya Umat, 2007) 
yang menyebabkan istri yang lain menderita, maka dianjurkan untuk menikahi seorang saja.

3. Poligami dilakukan bukan dasar atas hawa nafsu belaka tetapi memerlukan pertimbangan-pertimbangan lain yang lebih penting. Diantara untuk melindungi kaum wanita yang semakin banyak dan terutama janda-janda yang memerlukan santunan jiwa dan raganya.

\section{Pengertian Positivisme}

Positivisme adalah suatu aliran filsafat yang menyatakan ilmu alam sebagai satu-satunya sumber pengetahuan yang benar dan menolak aktifitas yang berkenaan dengan metafisik. Tidak mengenal adanya spekulasi, semua didasarkan pada data empiris. Sesungguhnya aliran ini menolak adanya spekulasi teoritis sebagai suatu sarana untuk memperoleh pengetahuan (seperti yang diusung oleh kaum idealisme khususnya idealisme Jerman Klasik).

Pengetahuan positif merupakan puncak pengetahuan manusia yang disebutnya sebagai pengetahuan ilmiah. Sesuai dengan pandangan tersebut kebenaran metafisik yang diperoleh dalam metafisika ditolak, karena kebenarannya sulit dibuktikan dalam kenyataan. Auguste Comte mencoba mengembangkan Positivisme ke dalam agama atau sebagai pengganti agama. Hal ini terbukti dengan didirikannya Positive Societies di berbagai tempat yang memuja kemanusiaan sebagai ganti memuja Tuhan. Perkembangan selanjutnya dari aliran ini melahirkan aliran yang bertumpu kepada isi dan fakta-fakta yang bersifat materi, yang dikenal dengan Materialisme. $^{6}$

\section{E. Positivisme Dalam Ranah Hukum Keluarga Islam .}

Sebelum berbicara tentang Hukum Keluarga, alangkah lebih baik kita mengetahui Hukum Islam yang didalamnya dipelajari Filsafat hukum Islam, Didalam Oxford English Dictionary, Hukum adalah: "Sekumpulan aturan, baik yang berasal dari aturan formal maupun

${ }^{6}$ Drs. Atang Abdul Hakim, Filsafat Umum, (Bandung, Pustaka Setia, 2008), h. 296. 
adat, yang diakui oleh masyarakat dan bangsa tertentu sebagai mengikat bagi anggotanya" Bila Hukum dihubungkan dengan Islam, maka Hukum Islam berarti: "Seperangkat peraturan berdasarkan wahyu Allah dan Sunnah Rasul tentang tingkah laku manusia mukallaf diakui dan diyakini berlaku dan mengikat untuk semua umat yang beragama Islam”.

Dari definisi yang dikemukakan diatas dapat dipahami bahwa hukum Islam mencakup Hukum Syariah dan Hukum Fiqih, karena arti syariah dan fiqih terkandung didalamnya. Kata Hukum Islam tidak ditemukan sama sekali didalam al-Qur'an dan literatur hukum dalam Islam. Yang ada dalam al-Qur'an adalah kata syariah, fiqih, hukum Allah dan yang seakar dengan Menurut Mustafa Abdul Raziq bahwa ilmu ushul fiqih adalah ilmu Filsafat Hukum Islam..

Jadi, berijtihad dengan mempergunakan akal dalam permasalahan hukum Islam, yang pada hakikatnya merupakan pemikiran falsafi itu, direstui oleh Rasulullah. Bahkan lebih tegas lagi Allah menyebutkan bahwa mempergunakan akal dan pikiran atau berfikir falsafi itu sangat perlu dalam memahami berbagai persoalan. Allah berfirman dalam surah al-Baqarah ayat 179

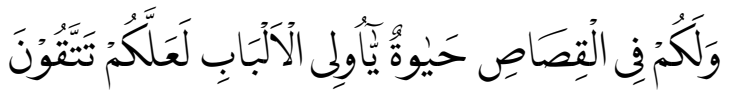

"Dan dalam qisas itu ada (jaminan) kehidupan bagimu, wahai orangorang yang berakal, agar kamu bertakwa.” (Q.S. Al-Baqarah/179)

Ayat diatas menunjukkan bahwa mempergunakan akal pikiran untuk menangkap makna yang terkandung dalam syari'at sesuai dengan petunjuk al-Qur'an termasuk yang dianjurkan.

Positivisme dalam hukum Islam, benar-benar harmonis antara satu sama lain. Pernyataan ini sesuai dengan firman Allah:

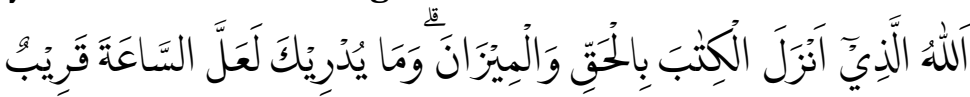

“Allah yang menurunkan Kitab (Al-Qur'an) dengan (membawa) kebenaran dan neraca (keadilan). Dan tahukah kamu, boleh jadi hari Kiamat itu sudah dekat?” (Q.S. Asy-Syura/17)

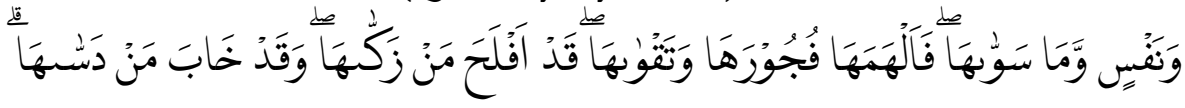


"Demi jiwa serta penyempurnaan (ciptaan)nya, maka Dia mengilhamkan kepadanya (jalan) kejahatan dan ketakwaannya, sungguh beruntung orang yang menyucikannya (jiwa itu), dan sungguh rugi orang yang mengotorinya, (Q. S. al-Syams/91: 7-10.) ${ }^{7}$

Secara singkat Hukum Keluarga didefinisikan sebagai hukum yang mengatur kehidupan keluarga, yang dimulai dari awal pembentukan keluarga, Tujuannya adalah untuk mengatur hubungan suami-istri dan anggota keluarga. ${ }^{8}$

Dari keterangan diatas dapat kita pahami antara positivisme dengan Hukum keluarga Islam memiliki relevansi yang harmonis, di mana Hukum Keluarga Islam adalah merupakan bagian dari Fiqh Islam yang merupakan Produk dari manusia yang bersifat dinamis dan bukan statatis, yang memerlukan pemahaman yang kritis yang dengan memakai rasio dan empiris agar mendapatkan fakta-fakta yang aktual dan betul-betul nyata serta sesuai dengan keadaan zaman saat ini.Salah satu contoh yang bisa kita angkat adalah tentang ayat Poligami apakah pada saat ini ayat itu sangat relevan dengan konteks zaman saat ini. zaman yang ada, banyak dari umat manusia yang pro atau kontra dari yang menghalalkan sampai yang mengharamkan.

\section{F. Analisis Poligami Dalam Pandangan Positivisme}

1. Poligami Menurut Perspektif Filsafat Hukum Islam

Dalam persfektif Filsafat Hukum Islam, secara garis besar pandangan para ulama secara keseluruhan terhadap poligami dapat di golongkan pada tiga pendapat, yaitu:

a. Golongan pertama adalah ulama yang membolehkan menikahi wanita lebih dari satu dengan syarat-syarat dan kondisi tertentu yaitu apabila dalam keadaan darurat, jadi apabila tidak dalam keadaan darurat maka di haramkan. Adapun contohnya yakni apabila Istri sakit-sakitan dan mempunyai penyakit yang tidak dapat di sembuhkan lagi atau mandul maka suami di perbolehkan

\footnotetext{
${ }^{7}$ A.khudori Sholeh, Filsafat Islam, (Yogyakarta, Pustaka Pelajar, 2012), h. vii

${ }^{8}$ Abd al-Wahhab Khalaf, Ilm Usul al-Fiqh, cet ke-8, (Kairo: Maktabah al-Da'wah al-Islamiyah, 1996), h. 32
} 
berpoligami, Di antara tokoh ulama yang termasuk golongan yang disebut sebagai pemikir kontemporer dan perundangan-undangan modern ini adalah Muhammad Abduh, Sayyid Qutb, Fazlur Rahman, Amina Wadud dan lain-lain.

b. Golongan kedua memperbolehkan suami mempunyai istri maksimal empat secara mutlak, dengan syarat mampu mencukupi nafkah keluarga dan mampu berbuat adil terhadap istri-istrinya. Pendapat ini di pegangi oleh mayoritas pemikir ulama klasik dan pertengahan baik ulama mazhab fiqh maupun tafsir. ${ }^{9}$

c. Golongan ketiga berpendapat bahwa berpoligami adalah haram, tokoh-tokoh yang mengharamkan poligami adalah al-Haddad dan Habib $\mathrm{Bu}$ Ruqayba, mereka mengharamkan poligami yaitu menurut al-Hadad di karenakan dengan turunnya surah An-Nisa ayat 129: "Dan kamu sekali-kali tidak akan dapat berlaku adil di antara isteri-isteri(mu), walaupun kamu sangat ingin berbuat demikian, Karena itu janganlah kamu terlalu cenderung (kepada yang kamu cintai), sehingga kamu biarkan yang lain terkatungkatung. dan jika kamu mengadakan perbaikan dan memelihara diri (dari kecurangan), Maka Sesungguhnya Allah Maha Pengampun lagi Maha Penyayang”. (Q.S. An-Nisa 129)

Mestinya poligami harus dicegah karena tujuan perkawinan menurut Al-Haddad adalah untuk menciptakan keluarga sakinah, mawaddah dan rahmah. sementara dalam kenyataan poligami mengakibatkan sulit sekali melahirkan kehidupan yang harmonis dan tentram antara suami istri dan anak-anak.

Dari ketiga ijtihad tentang poligami ini, saya sendiri lebih sependapat dengan ijtihad golongan pertama seperti yang dikemukakan oleh Muhammad Abduh bahwa poligami adalah suatu tindakan yang tidak boleh atau haram, akan tetapi poligami hanya mungkin bisa di lakukan seorang suami dalam dalam hal-hal tertentu. ${ }^{10}$

${ }^{9}$ http://makalahmajannaii.blogspot.com/2012/06/problematika-poligami-dalampersfektif.html(31-12-12)

${ }^{10}$ ibid 
Kebolehan poligami sangat tergantung pada kondisi situasi dan tuntutan zaman. Karena itu, konteks sejarah ketika turunnya ayat Alqur'an (asbabun nuzul) tentang kebolehan berpoligami harus dibaca secara cermat dan jernih, yaitu asbabun nuzul ayat Al-qur'an tersebut turun seusai perang uhud, ketika banyak pejuang Islam (mujahidin) yang gugur di medan perang, sebagai konsekuensinya, banyak anak yatim dan janda yang ditinggal mati oleh ayah dan suaminya. Akibatnya, banyak anak yatim terabaikan dalam kehidupan, pendidikan dan masa depannya.

Muhammad Abduh sangat keras dalam mengharamkan poligami, tetapi masih ada kemungkinan untuk melakukannya, yaitu apabila ada ada tuntutan yang benar-benar mengharuskan seseorang melaksanakannya, Larangan atau kebolehan melakukan poligami menurut Abduh lebih banyak di tentukan oleh tuntuatan zaman yaitu keadaan darurat.

Pendapat berikutnya di kemukakan oleh Fazlur Rahman, Alqur'an surah An-Nisa ayat 3 memang menganjurkan poligami dengan disertai syarat bahwa para suami mampu berbuat adil dengan diikuti dengan penegasan "jika engkau khawatir tidak mampu berbuat adil, cukuplah hanya dengan seorang istri".Selanjutnya pada Al-qur'an surah An-Nisa ayat 129 di tegaskan "kamu sekalian kali tidak akan berbuat adil terhadap istri-istrimu walaupun kamu sangat menghendaki demikian".

Fazlur Rahman tidak sependapat bahwa frase berlaku adil dalam surat An-Nisa ayat 3 hanya terbatas perlakuan lahiriah, Jika frase tersebut hanya pada perlakuan lahiriah saja niscaya tidak ada penegasan dan peringatan yang di sebutkan dalam ayat An-Nisa 129. Dengan memandang izin poligami bersifat temporer dan memandang bahwa yang di maksud dan yang di tuju Al-qur'an yang sebenarnya adalah menegakkan monogami, atau menyelamatkan Q.S. An-Nisa ayat 3 dan 129 dari pengertian kontradiktif. ${ }^{11}$

11 Rif'at s nawawi, (Sikap Islam Tentang Poligami dan Monogami dalam Problematika Hukum Islam Kontomporer, (Jakarta: Lembaga Studi Islam dan Kemasyarakatan, 1996), h. 108-109. 
Sedangkan Sayyid Qutub dalam kitabnya yang berjudul "fi zilal al qur'an" mengatakan bahwa poligami merupakan perbuatan rukhsah, maka hanya boleh dilakukan dalam keadaan darurat, yang benarbenar mendesak. Kebolehan ini pun masih di syaratkan bisa berbuat adil terhadap istri-istri. Keadilan yang di tuntut di sini termasuk dalam bidang nafkah, muamalah, pergaulan, serta pembagian malam.sedang bagi calon suami yang tidak bisa berbuat adil, maka diharuskan cukup satu saja. ${ }^{12}$

\section{Poligami Menurut Positivisme}

Positivisme adalah suatu aliran filsafat yang menyatakan ilmu alam sebagai satu-satunya sumber pengetahuan yang benar dan menolak aktifitas yang berkenaan dengan metafisik. Tidak mengenal adanya spekulasi, semua didasarkan pada data empiris, di mana semua data-data tersebut berdasarkan fakta-fakta yang nyata dan hasilnyapun memiliki kegunaan dan kemanfaatan yang pasti. ${ }^{13}$

Dari pembahasan di atas penulis dapat menganalisis bahwa permasalahan poligami apabila ditinjau dari positivisme sangat tidak relevan pada konteks saat ini, hal ini sesuai yang dikemukakan muhammad abduh, Menurut Abduh poligami yang di lakukan dengan tujuan hanya untuk kesenangan hukumnya haram. Apabila alasannya di maksudkan hanya untuk memenuhi kebutuhan biologis semata menjadi tidak boleh, tetapi jika alasannya karena darurat maka kemungkinan dibolehkannya untuk melakukan tetap ada, dan banyak dari (kaum lelaki) yang melakukan poligami hanya berdasarkan nafsyu syahwat, tanpa melihat latar belakang munculnya ayat tersebut (asbabun nuzul) yang lebih menekankan pada pemeliharaan anakanak yatim serta wanita-wanita yang ditinggal mati suaminya dalam peperangan.

Dalam pembahasan ini positivisme lebih condong kepada mengharamkan poligami dari pada membolehkan, hal ini berkaitan dengan hasil yang didapat dari epistemologi tersebut, bahwa semua

12 ibid

13 Atang Abdul Hakim, Filsafat Umum, (Bandung, Pustaka Setia, 2008), h. 296. 
sumber ilmu pengetahuan hanya berdasarkan rasio dan fakta-fakta empiris yang nyata dan memiliki kegunaan yang pasti. Apabila dikaitkan pada konteks saat ini poligami yang dilakukan banyak pria lebih merugikan wanita dari pada membawa keuntungan dan kemanfaatan bagi pria, maka poligamipun diharamkan karena lebih banyak merugikan banyak pihak dari pada menguntungkan satu pihak.

Positivisme adalah epistemologi yang sangat erat kaitannya dengan rasio dan fakta-fakta empiris, positivisme juga merupakan contiunitas dari rasionalitas dan empirisme yang secara tidak langsung mengiyakan aliran ini, hanya postivisme disini lebih kepada tekstualitas hukum dan mempunyai kegunaan yang pasti, maka penulis dapat menyimpulkan bahwa disinilah peran rasio dan empiris bermain, walaupun poligami telah menjadi tekstualitas hukum yang ada di dalam Al-Quran dan telah menjadi pedoman bagi umat islam, tetapi apakah poligami pada konteks zaman saat ini lebih membawa kemashalatan atau mungkin lebih banyak merugikan wanita?, sebuah pertanyaan besar yang harus dijawab oleh setiap manusia yang ingin melakukan poligami, sedangkan makna inti dari positivisme itu sendiri adalah epistemolgi atau sumber ilmu pengetahuan yang memilki kegunaan dan memilki manfaat yang pasti.

Sehingga sudah tepat bila positivisme memandang poligami lebih banyak membawa resiko atau mudharat dari pada manfaatnya dan lebih mengharamkannya dari pada membolehkan, poligami bisa menjadi sumber konflik dalam kehidupan keluarga baik konflik antara suami dan istri ataupun konflik istri beserta anak-anaknya.

Di samping itu poligami mempunya implikasi negative yang tidak sesuai dengan tujuan postivisme yaitu secara psikologis semua istri akan merasa sakit hati bila melihat suaminya karena di dorong oleh rasa cinta setianya yang dalam kepada suaminya, umumnya istri mempercayai dan mencintai suaminya sepenuh hati sehingga dalam dirinya tidak ada lagi ruang cinta terhadap laki-laki lain. Istri selalu berharap suaminya berlaku sama terhadap istrinya, Karena itu istri tidak dapat menerima suaminya membagi cintanya kepada perempuan lain. 
Faktor kedua, istri merasa imperior seolah-olah suaminya berbuat demikian lantaran ia tidak mampu memenuhi kebutuhan biologisnya. Sudah sepatutnya istri yang demikian merelakan suaminya melakukan poligami,Bila suaminya berkehendak untuk melakukan poligami sebagai bukti tanggung jawabnya dalam rangka melestarikan kehidupan keluarga dan memakmurkan bumi, maka inilah dampak yang ditimbulkan dalam berpoligami sehingga positivisme lebih cenderung mengharamkan dari pada membolehkan dalam batas-batas tertentu.

\section{Penutup}

\section{Kesimpulan}

Dari pembahasan di atas maka penulis dapat menyimpulkan bahwa:

1. Poligami merupakan praktik pernikahan kepada lebih dari satu suami atau istri (sesuai dengan jenis kelamin orang bersangkutan) sekaligus pada suatu saat (berlawanan dengan monogami, di mana seseorang memiliki hanya satu suami atau istri pada suatu saat, Poligami dalam Islam baik dalam hukum maupun praktiknya, diterapkan secara bervariasi di tiap-tiap negara dengan mayoritas penduduk beragama Islam.

2. Positivisme adalah suatu aliran filsafat yang menyatakan ilmu alam sebagai satu-satunya sumber pengetahuan yang benar dan menolak aktifitas yang berkenaan dengan metafisik. Tidak mengenal adanya spekulasi, semua didasarkan pada data empiris, dan memiliki manfaat dan kegunaan yang pasti. Kaitan Positivisme dalam ranah Hukum keluarga Islam benar-benar harmonis antara satu sama lain. Pernyataan ini sesuai dengan firman Allah,QS. Asyura': 17.

Dalam persfektif Filsafat Hukum Islam,secara keseluruhan para ulama membagi tiga pendapat, yaitu:

a. Golongan pertama adalah ulama yang membolehkan menikahi wanita lebih dari satu dengan syarat-syarat dan kondisi tertentu yaitu apabila dalam keadaan darurat, jadi apabila tidak dalam keadaan darurat maka di haramkan. 
b. Golongan kedua memperbolehkan suami mempunyai istri maksimal empat secara mutlak, dengan syarat mampu mencukupi nafkah keluarga dan mampu berbuat adil terhadap istri-istrinya. Pendapat ini di pegangi oleh mayoritas pemikir ulama klasik dan pertengahan baik ulama mazhab fiqh maupun tafsir.

c. Golongan ketiga berpendapat bahwa berpoligami adalah haram, tokoh-tokoh yang mengharamkan poligami adalah al-Haddad dan Habib Bu Ruqayba, mereka mengharamkan poligami yaitu menurut al-Hadad di karenakan dengan turunnya surah An-Nisa ayat 129.

Permasalahan poligami apabila ditinjau dari positivisme sangat tidak relevan pada konteks saat ini sehingga positivisme lebih condong kepada mengharamkan poligami dari pada membolehkan, walaupun poligami telah menjadi tekstualitas hukum yang ada di dalam Al-Quran dan telah menjadi pedoman bagi umat islam, tetapi apakah poligami pada konteks zaman saat ini lebih membawa kemashalatan atau mungkin lebih banyak merugikan wanita, disinilah peran rasio dan empiris bermain karena makna inti dari positivisme itu sendiri adalah epistemolgi atau sumber ilmu pengetahuan yang memilki kegunaan dan memilki manfaat yang pasti.

\section{Daftar Pustaka}

Ash- Shadr, M. Baqir, Falsafatuna, Bandung, Penerbit Mizan,1995

Faqih, Khoyin Abu, Poligami Solusi atau Masalah.Jakarta: Al-I’tishom Cahaya Umat, 2007

Hakim, Atang Abdul, Filsafat Umum, Bandung, Pustaka Setia, 2008

http://makalahmajannaii.blogspot.com/2012/06/problematikapoligami-dalam-persfektif.html

Khalaf, Abd al-Wahhab, Ilm Usul al-Fiqh, cet ke-8, Maktabah al-Da'wah al-Islamiyah

Mufidah, Isu -Isu Gender kontemporer (Dalam Hukum Keluarga), Malang, UIN-Maliki Press, 2010 
Mulyati, Sri, Relasi Suami Istri dalam Islam (Jakarta: PSW UIN Syarif Hidayatullah, 2004

Nawawi, Rif'at s, Sikap Islam Tentang Poligami dan Monogami dalam Problematika Hukum Islam Kontomporer, Jakarta: Lembaga Studi Islam dan Kemasyarakatan, 1999

Sholeh, A.khudori, Filsafat Islam, Yogyakarta, Pustaka Pelajar, 2012 